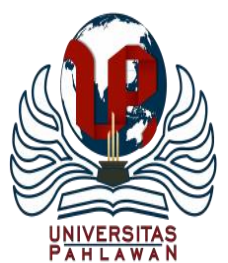

Edukatif : Jurnal Ilmu Pendidikan Volume 3 Nomor 6 Tahun 2021 Halm 3565 - 3578

EDUKATIF: JURNAL ILMU PENDIDIKAN

Research \& Learning in Education

https://edukatif.org/index.php/edukatif/index

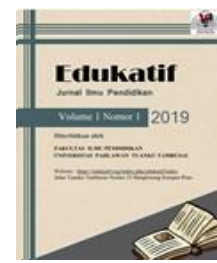

\title{
Implementasi Pendidikan Karakter Integritas Sub Nilai Kejujuran melalui Program Kantin Kejujuran di Sekolah Dasar
}

\author{
Annisa’ Auliyairrahmah ${ }^{1 凶}$, Sukron Djazilan $^{2}$, Nafiah $^{3}$, Sri Hartatik $^{4}$ \\ Universitas Nahdlatul Ulama Surabaya, Indonesia ${ }^{1,2,3,4}$ \\ E-mail : annisaauliyairrahmah045.sd17@ student.unusa.ac.id ${ }^{1}$, syukrondjazilan@unusa.ac.id ${ }^{2}$, \\ nefi_23@unusa.ac.id ${ }^{3}$, titax@ unusa.ac.id $^{4}$
}

\begin{abstract}
Abstrak
Penelitian ini dilatarbelakangi oleh karakter integritas sub nilai kejujuran dikalangan para siswa sekolah dasar masih sangat rendah yang dapat di buktikan dengan beberapa kasus yang ada. Tujuan penelitian ini untuk mendekripsikan implementasi pendidikan karakter integritas sub nilai kejujuran melalui program kantin kejujuran di sekolah dasar, kendala yang dihadapi dan upaya untuk mengatasi kendala tersebut. Penelitian ini menggunakan pendekatan kualitatif jenis penelitian studi literatur/literature review. Teknik pengumpulan data yang digunakan adalah teknik dokumentasi berupa artikel pada google scholar. Analisis data menggunakan model Miles, Hubermen yaitu data condensation, data display, dan conclusing drawing/verifictoin. Uji keabsahan data yang digunakan pada penelitian ini, adalah uji kredibilitas dan dependabilitas. Hasil penelitian ini menunjukkan bahwa: 1) implementasi pendidikan karakter integritas di sekolah dasar dilaksanakan dengan 4 kegiatan yaitu kegiatan rutin, kegiatan spontan, kegiatan keteladanan, dan pengondisian. serta 2 sistem yaitu sistem self-service dan pelibatan siswa. 2) kendala yang dihadapi ialah masih terdapat beberapa siswa yang kesulitan untuk jujur, adanya selisih pendapatan, dan belum optimal dalam pelaksanaannya. 3) upaya yang dilakukan untuk mengatasinya yaitu dengan memberikan teguran, pembinaan dan peningkatan mutu pelayanan dan manajemen pengelolaan.
\end{abstract}

Kata Kunci: Pendidikan karakter; kejujuran; kantin kejujuran.

\begin{abstract}
The research is motivated by the character of the integrity of the sub-value of honesty among elementary school students is still very low wich can be proven by several existing cases. The purpose of this study is is to describe the implementation of integrity character education through the honesty canteen program in elementary school, the obstacles faced and effort to overcome these obstacles. This study uses a qualitative appoarch to the type of study literaturel literature review research. The data collection technique used ia a documentation technique in the form of articles on Google Scholar. Data analysis uses the Miles, Hubermen model, namely data condensation, data display, and conclusing drawing/verfication. Test the validity of the data used in the study, is a test of credibility and dependability. The result of this study indicate that: 1) the implementation of integrity character education in elementary school is carried out with 4 activities, namely routine activities, spontaneous activities, exemplary activities, and conditioning. And 2 systems, namely the self-service system and student involement. 2) the obstacles faced are that there are still some students who have difficulty being honest, there is a difference in income, and it is not optimal in its implementation. 3) efforts are being made to overcome services and management.
\end{abstract}

Keywords: Character education; honesty; honesty canteen.

Copyright (c) 2021 Annisa’ Auliyairrahmah, Sukron Djazilan, Nafiah, Sri Hartatik

$\triangle$ Corresponding author

Email : annisaauliyairrahmah045.sd17@student.unusa.ac.id

DOI : https://doi.org/10.31004/edukatif.v3i6.939 
3566 Implementasi Pendidikan Karakter Integritas Sub Nilai Kejujuran melalui Program Kantin Kejujuran di Sekolah Dasar - Annisa' Auliyairrahmah, Sukron Djazilan, Nafiah, Sri Hartatik

DOI: https://doi.org/10.31004/edukatif.v3i6.939

\section{PENDAHULUAN}

Berbicara mengenai perilaku manusia, pendidikan menjadi aspek yang paling penting karena dalam pendidikan terjadi pembinaan tingkah laku perbuatan agar manusia dapat berpikir, berperasaan, dan bertindak lebih baik daripada sebelumnya (Juanda, 2010). Pendidikan merupakan suatu upaya untuk menjadikan manusia yang memiliki akhlak dan perilaku layaknya seorang manusia yang sesungguhnya. Pendidikan pada dasarnya memberikan pendewasaan kepada manusia untuk berpikir lebih baik secara lahir dan batin (Agra, 2021). Proses pendidikan melekat dalam diri manusia sejak berada di dalam kandungan hingga akhir hayat, manusia terus mengalami proses pendidikan. Beberapa fakta dilapangan memang tidak sejalan dengan hal tersebut. Perilaku tidak jujur seperti korupsi, suap, dan lain sebagainya masih sering kita temui, hal ini tentu bertolak belakang dengan tujuan pendidikan nasional. Seiring dengan berkembangnya zaman, banyak dijumpai beberapa kecurangan yang semakin kesini semakin dianggap sepele, yang tanpa disadari akan menjadikan bad habits. Pada saat ini banyak siswa-siswa yang kurang dibimbing oleh orang tua karena juga keterlibatan orang tua dengan guru yang kurang baik (Esmael \& Nafiah, 2018). Selain itu pendidikan kita seseungguhnya melewatkan atau mengabaikan beberapa dimensi penting dalam pendidikan, yaitu olah raga (kinestetik), olah rasa (seni), dan olah hati (etik dan spiritual) (Effendy, 2016). Apa yang selama ini kita lakukan baru sebatas olah pikir yang menumbuhkan kecerdasan akademis, tanpa mengingat peluang adanya kemerosotan pada karakter peserta didik. Ketidakjujuran yang sangat menonjol di kalangan para siswa yaitu kebiasaan mencontek namun, tidak hanya melulu tentang mencontek beberapa kasus menunjukkan terdapat beberapa siswa sekolah dasar di Indonesia yang mempunyai perilaku dan karakter yang kurang baik bahkan menyimpang dari nilai - nilai karakter yang ada. Beberapa kasus ini siswa sekolah dasar adalah yang terjadi di Makassar, dilansir oleh iNewsSulses.id polisi menangkap siswa kelas 4 SD saat asyik bermain game di warnet jalan Deppasawi Dalam, kota Makassar, kronoliginya siswa tersebut diketahui telah mencuri perlengkapan sembahyang di Vihara Girinaga.

Untuk mengatasi permasalahan dan kasus - kasus yang terjadi tersebut, pemerintah telah mengembangkan pendidikan karakter disekolah. Menurut Permendikbud Nomor 20 Tahun 2018 Tentang Penguatan pendidikan Karakter Pada Satuan Pendidikan Formal. Pada pasal 2 Permendikbud Nomor 20 Tahun 2018 bahwa PPK dilaksanakan dengan menerapkan nilai - nilai yang terkandung dalam Pancasila dalam pendidikan karakter terutama meliputi nilai - nilai religious, jujur, toleran, disiplin, bekerja, keras, kreatif, mandiri, demokratis, rasa ingin tahu, semangat kebangsaan, cinta tanah air, menghargai prestasi, komunikatif, cinta damai, gemar membaca, peduli lingkungan, peduli social, dan bertanggung jawab. Nilai tersebut merupakan suatu perwujudan dari 5 (lima) nilai utama yang saling berkaitan religious, nasionalisme, kemandirian, gotong royong, dan integritas. Tujuan pendidikan karakter pada intinya adalah untuk membentuk bangsa yang tangguh, bermoral, berakhlak mulia, bertoleren, bergotong royong, berjiwa patriotik, berorientasi ilmu pengetahuan teknologi yang semuanya dijiwai oleh iman dan taqwa kepada Tuhan Yang Maha Esa berdasarkan Pancasila (Cindra Hendriana \& Jacobus, 2016).

Menurut (Hidayatullah, 2010) menjelaskan ada tempat yang strategis untuk membentuk karakter siswa yaitu lembaga pendidikan, khususnya sekolah. Hal ini tentu dimaksudkan agar siswa dalam segala sikap, ucapan serta perilaku mencerminkan suatu karakter yang baik. Disini pendidikan karakter sangat penting untuk ditanamkan sejak dini. Pendidikan karakter biasa dimaksudkan sebagai wadah untuk penanaman nilai nilai karakter kepada seluruh warga sekolah yang meliputi beberapa unsur seperti pengetahuan, kesadaran, dan tindakan. Yang nantinya pendidikan karakter tersebut dapat di terapkan kepada Tuhan Yang Maha Esa, lingkungan sekitar, diri sendiri, sesama manusia, maupun kebangsaan sehingga menjadi manusia insan kamil yang berakhlak mulia seperti yang dikemukakan oleh (Narwanti, 2011). Pendidikan karakter tentu memiliki fungsi sebagai wadah pembentukan dan pengembangan potensi, perbaikan dan penguatan, serta penyaring untuk menjadikan seorang individu yang mempunyai pemikiran, hati, dan perbuatan yang baik. Sedangkan 
3567 Implementasi Pendidikan Karakter Integritas Sub Nilai Kejujuran melalui Program Kantin Kejujuran di Sekolah Dasar - Annisa' Auliyairrahmah, Sukron Djazilan, Nafiah, Sri Hartatik

DOI: https://doi.org/10.31004/edukatif.v3i6.939

karakter merupakan satu aspek kepribadian manusia (Rahayu, 2016). Pendidikan karakter dimaknai sebagai suatu sistem penanaman nilai-nilai karakter kepada semua warga sekolah yang meliputi komponen pengetahuan, kesadaran, atau kemauan, dan tindakan untuk melaksanakan nilai-nilai tersebut, baik terhadap Tuhan Yang Maha Esa, diri sendiri, sesama, lingkungan, maupun kebangsaan sehingga menjadi manusia insan kamil (Samani \& Hariyanto, 2013). Hal inilah yang diharapkan dapat membangun kehidupan bangsa yang lebih baik dan dapat membentuk serta menjadikan siswa sebagai warga negara yang mempunyai tanggung jawab, jujur, serta dapat menyaring kebudayaan negara lain yang juga harus disesuaikan dengan kebudayaan negara sendiri. Salah satu karakter yang perlu ditekankan semenjak dini adalah kejujuran (Khotimah, 2020). Senada dengan pendapat tersebut bahwa sifat kejujuran perlu ditanamkan dalam diri seseorang sedini mungkin, karena kejujuran merupakan tanggung jawab moral seseorang terhadap nilai-nilai dan norma-norma agamadan masyarakat (Nawawi, 2017). Jujur adalah mengatakan apa adanya, mempunyai sifat terbuka, dan tentu konsisten dengan apa yang dikatakan dan dilakukan dengan kata lain kedua hal tersebut saling berintegritas, dapat dipercaya dan tidak curang. Menurut (Kesuma et al., n.d.) memaparkan bahwa kejujuran berasal dari kata jujur, yang sering diartikan dengan "adanya kesamaan antara kenyataan dan apa yang diucapkan". Kejujuran merupakan sebuah sifat, sikap atau kebiasaan seorang individu yang dapat dipercaya dalam perbuatan, perkataan dan pekerjaan baik untuk dirinya sendiri maupun untuk orang lain, serta senantiasa mengucapkan segala hal apa adanya juga selaras antara yang diucapkan dengan yang telah dilakukan. Sikap jujur dalam diri seseorang tidak dapat diperoleh secara instan, harus ada pembiasaan pembiasaan diri sejak masih kecil.

Menurut (Sitorus \& Lasso, 2021) Implementasi pendidikan karakter dapat dilakukan melalui integrasi dalam mata pelajaran melalui Rencana Pelaksanaan Pembelajaran (RPP) dan silabus; integrasi dalam muatan lokal; kegiatan pengembangan diri berupa pembudayaan dan pembiasaan. Implementasi pendidikan karakter dapat dilaksanakan melalui program kantin kejujuran yang mana Program ini juga termasuk ke dalam program pengembangan diri yang ada di lingkungan sekolah. Program ini di dalamnya meliputi kegiatan rutin, kegiatan spontan, keteladanan, dan pengondisian (Subekti, 2018). Program ini digagas oleh KPK untuk memperingati hari korupsi yang jatuh pada tanggal 9 desember. Menurut (Kurniawan, 2013) Kantin jujur adalah ruang tempat menjual makanan dan minuman disekolah kepada peserta didik dengan tujuan untuk melatih kejujuran para peserta didik. Menurut Kamus Besar Bahasa Indoneisa kantin adalah ruang tempat menjual makanan dan minuman (di sekolah, di kantor, di asrama dll) sedangkan kejujuran menurut Kamus Besar Bahasa Indonesia berasal dari kata "jujur" yang berimbuhan ke-an, yang berarti tidak berbohong, lurus hatinya, tidak melakukan perbuatan yang curang, ikhlas dan tulus. Dari paparan tersebut dapat disimpulkan bahwasannya jujur merupakan suatu tindakan atau pernyataan yang dilakukan sesuai faktanya sehingga dapat dipercaya dan berpengaruh bagi kesuksesan seseorang hal ini dikemukaan oleh (Mustaghfiroh, 2017). Hal tersebut adalah salah satu program pemerintah sebagai bentuk upaya untuk menjadikan generasi muda dalam mencegah perilaku tidak jujur dan membentuk karakter jujur siswa. Maka dari itu implementasi pendidikan karakter integritas dapat dilaksanakan melalui program kantin kejujuran dan diharapkan dapat mengatasi permasalahan yang ada di kalangan siswa sekolah dasar.

\section{METODE PENELITIAN}

Penelitian ini dilakukan menggunakan pendekatan kualitatif jenis penelitian literature review menurut Nazir jenis penelitian literature riview atau kepustakaan adalah penelitian dengan studi penelaahan sistematis terhadap buku-buku, literatur-literatur, dan laporan-laporan yang ada hubungannya dengan masalah yang ingin dipecahkan. Sehubungan dengan permasalahan yang diangkat oleh peneliti yaitu implementasi pendidikan karakter integritas sub nilai kejujuran melalui kantin kejujuran di sekolah dasar, kendala yang di hadapi dan upaya yang dilakukan untuk mengatasi kendala yang dihadapi dalam implementasi pendidikan 
karakter integritas sub nilai kejujuran melalui kantin kejujuran disekolah dasar. Literatur yang dikaji merupakan literatur yang sesuai dengan topik pembahasan pada penelitian ini, jumlah literatur yang dikaji berjumlah 12 sumber data yang relevan, kemudian alasan pemilihan literatur serta tolok ukur dalam penetapan literatur yang dijadikan sebagai objek kajian yaitu meliputi: relevan dengan variabel pada penelitian ini, berasal dari sumber terepercaya, dan tahun terbit sumber data yang digunakan ialah 10 tahun terakhir. kemudian pada penelitian ini teknik pengumpulan data yang digunakan adalah teknik dokumentasi berupa artikel pada google scholar. Populasi yang digunakan yaitu dokumen tertulis mengenai penelitian implementasi pendidikan karakter integritas sub nilai kejujuran melalui kantin kejujuran disekolah dasar. Sedangkan teknik pengambilan sampel pada penelitian ini adalah teknik purposive sampling. Teknik purposive sampling merupakan teknik pengambilan sampel dengan pertimbangan tertentu. Kata kunci yang digunakan dalam penelusuran di google scholar adalah "Pendidikan karakter integritas sub nilai kejujuran" dan "Kantin kejujuran". Uji keabsahan data yang digunakan pada penelitian ini, adalah uji kredibilitas dan dependabilitas. Data yang dikumpulkan kemudian dianalisis menggunakan model analisis data menurut Miles, Hubermen yaitu data condensation, data display, dan conclusing drawing/verifictoin. Tahapan penelitian dilakukan dimulai dengan menyeleksi, memfokuskan masalah dan menyederhanakan sumber data literatur yang sudah dikumpulkan, kemudian mendisplay data yang telah dikerucutkan sehingga dapat ditarik sebuah kesimpulan, dan prosedur tahapan yang terakhir ialah verifikasi data, sejak awal pengumpulan data, peneliti telah membuat simpulan - simpulan sementara. Dalam tahap akhir simpulan - simpulan tersebut harus dicek kembali yakni yang disebut dengan verifikasi pada catatan yang telah dibuat oleh peneliti dan selanjutnya kearah simpulan yang lebih matang.

\section{HASIL DAN PEMBAHASAN PENELITIAN}

Hasil penelitian ini di display dalam bentuk tabel, yang berdasarkan pada hasil analisis data yang dilakukan terhadap sumber data yang dilakukan sesuai dengan tujuan penelitian ini.

\begin{tabular}{|c|c|c|c|c|c|c|}
\hline No. & Peneliti & Tahun & Judul Penelitian & Lokasi & $\begin{array}{c}\text { Metode } \\
\text { Penelitia } \\
\text { n }\end{array}$ & Temuan \\
\hline 1 & Yulianti & 2013 & \begin{tabular}{lr}
\multicolumn{2}{l}{ Kajian Kantin Jujur } \\
dalam Rangka \\
Peningkatkan \\
Pendidikan \\
di Tarakter \\
Dasar & untuk \\
Mewujudkan & Siswa \\
yang Kreatif & (Studi \\
Kasus di & Sdn \\
Panggungrejo & 04 \\
Kepanjen) &
\end{tabular} & $\begin{array}{l}\text { Sdn } \\
\text { Panggungrejo } \\
04 \text { Kepanjen }\end{array}$ & Kualitatif & $\begin{array}{lr}\text { Hasil } & \text { penelitian } \\
\text { menunjukkan } & \text { bahwa } \\
\text { pelaksanaan } & \text { kantin } \\
\text { kejujran di } & \text { SDN } \\
\text { Panggungrejo } 04 \text { ini } \\
\text { dilakukan deengan sistem } \\
\text { terstruktur. } \\
\text { koordinator pengelolaan, } \\
\text { ada petugas kantin } \\
\text { sebagai pengelola } \\
\text { keuangan dan pelibatan } \\
\text { siswa sebagai tugas piket } \\
\text { dalam membantu dalam } \\
\text { persiapan dan pembuatan } \\
\text { laporan dari awal hingga } \\
\text { akhir. Sedangkan jika ada } \\
\text { sanksi maka perinatan } \\
\text { atau hukuman akan } \\
\text { diberikan kepada wali } \\
\text { kelas dan komite selaku } \\
\text { perwakilan walimurid }\end{array}$ \\
\hline
\end{tabular}


3569 Implementasi Pendidikan Karakter Integritas Sub Nilai Kejujuran melalui Program Kantin Kejujuran di Sekolah Dasar - Annisa' Auliyairrahmah, Sukron Djazilan, Nafiah, Sri Hartatik

DOI: https://doi.org/10.31004/edukatif.v3i6.939

\begin{tabular}{|c|c|c|c|c|c|c|}
\hline No. & Peneliti & Tahun & Judul Penelitian & Lokasi & $\begin{array}{c}\text { Metode } \\
\text { Penelitia } \\
\text { n }\end{array}$ & Temuan \\
\hline & & & & & & disekolah tersebut. \\
\hline 2 & $\begin{array}{l}\text { Atika, } \\
\text { Nyimas. }\end{array}$ & 2016 & 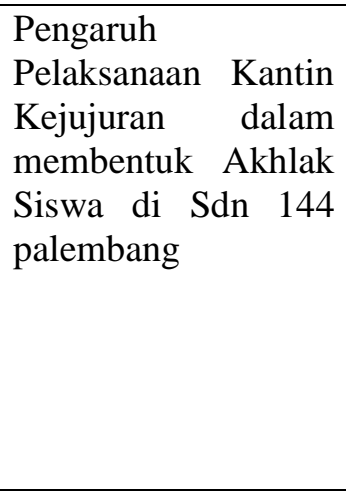 & $\begin{array}{l}\text { Sdn } 144 \\
\text { Palembang }\end{array}$ & $\begin{array}{l}\text { Kuantitat } \\
\text { if }\end{array}$ & $\begin{array}{lr}\text { Hasil } & \begin{array}{r}\text { penelitian } \\
\text { menunjukkan }\end{array} \\
\text { besarnwa "r" kerja } & \text { adalah } \\
0,980692744 & \text { yang } \\
\text { letaknya antara } 0,800 \\
\text { sampai 1,00. Maka dapat } \\
\text { diambil kesimpulan } \\
\text { bahwasannya pengaruh } \\
\text { penerapan } & \text { kantin } \\
\text { kejujuran di Sdn } 144 \\
\text { Palembang adalah tinggi. }\end{array}$ \\
\hline 3 & $\begin{array}{l}\text { Nawawi } \\
\text {, Imam. }\end{array}$ & 2017 & 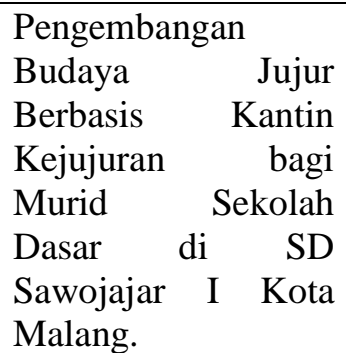 & $\begin{array}{l}\text { SD Sawojajar } \\
\text { I Kota } \\
\text { Malang }\end{array}$ & $\begin{array}{l}\text { Kualitatif } \\
\text { dan } \\
\text { Kuantitat } \\
\text { if }\end{array}$ & $\begin{array}{l}\text { Hasil penelitian } \\
\text { menunjukkan bahwa } \\
\text { budaya jujur berbasis } \\
\text { kantin kejujuran di SD } \\
\text { Sawojajar I Kota Malang } \\
\text { belum dilakukan secara } \\
\text { sitemk, sistematik dan } \\
\text { terprogram secara khusus. }\end{array}$ \\
\hline 4 & $\begin{array}{l}\text { Dewi } \\
\text { Subekti, } \\
\text { Fadzilah }\end{array}$ & 2018 & $\begin{array}{l}\text { Implementasi Nilai } \\
\text { Karakter Jujur } \\
\text { Melalui Program } \\
\text { Kantin Kejujuran di } \\
\text { Sdn Bsnyubening I } \\
\text { Gunungkidul. }\end{array}$ & $\begin{array}{l}\text { Sdn } \\
\text { Banyubening } \\
\text { I } \\
\text { Gunungkidul. }\end{array}$ & Kualitatif & 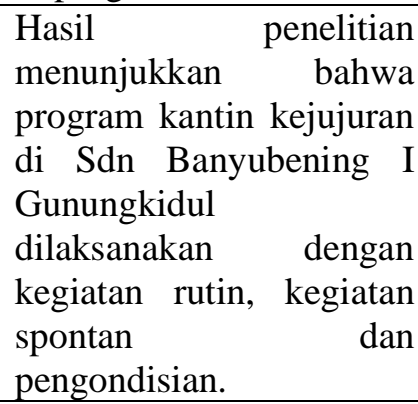 \\
\hline 5 & $\begin{array}{l}\text { Solikah, } \\
\text { Maratus }\end{array}$ & 2018 & $\begin{array}{l}\text { Pendidikan Karakter } \\
\text { Kejujuran Melalui } \\
\text { Kantin Kejujuran di } \\
\text { SD Muhammadiyah } \\
\text { Purwokerto }\end{array}$ & $\begin{array}{l}\text { SD } \\
\text { Muhammadi } \\
\text { yah } \\
\text { Purwokerto }\end{array}$ & Kualitatif & $\begin{array}{lr}\begin{array}{l}\text { Hasil } \\
\text { menunjukkan }\end{array} & \begin{array}{r}\text { penelitian } \\
\text { bahwa } \\
\text { pendidikan karakter }\end{array} \\
\text { melalui kantin kejujuran } \\
\text { di SD Muhammadiyah } \\
\text { Purwpkerto dilaksanakan } \\
\text { dengan menggunakan self } \\
\text { service system. }\end{array}$ \\
\hline 6 & $\begin{array}{l}\text { Puspita } \\
\text { Sari, } \\
\text { Gleni. }\end{array}$ & 2019 & $\begin{array}{lr}\text { Kajian Kantin Jujur } \\
\text { dalam Rangka } \\
\text { Peningkatkan } \\
\text { Pendidikan Karakter } \\
\text { di Tingkat } & \text { Sekolah } \\
\text { Dasar r untuk } \\
\text { Mewujudkan } & \text { Siswa } \\
\text { yang Jujur (Studi } \\
\text { Kasus di Sdn 2 } \\
\text { Kranji) }\end{array}$ & Sdn 2 Kranji & Kualtatif & 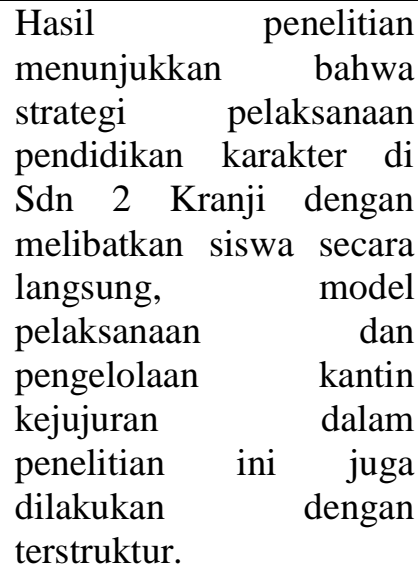 \\
\hline
\end{tabular}


3570 Implementasi Pendidikan Karakter Integritas Sub Nilai Kejujuran melalui Program Kantin Kejujuran di Sekolah Dasar - Annisa' Auliyairrahmah, Sukron Djazilan, Nafiah, Sri Hartatik

DOI: https://doi.org/10.31004/edukatif.v3i6.939

\begin{tabular}{|c|c|c|c|c|c|c|}
\hline No. & Peneliti & Tahun & Judul Penelitian & Lokasi & $\begin{array}{c}\text { Metode } \\
\text { Penelitia } \\
\text { n }\end{array}$ & Temuan \\
\hline 7 & $\begin{array}{l}\text { Anam, } \\
\text { Khoirul, } \\
\& \\
\text { Sakiyati } \\
\text { Devi IIs }\end{array}$ & 2019 & $\begin{array}{l}\text { Kantin Kejujuran } \\
\text { sebagai Upaya } \\
\text { Pembentukan } \\
\text { Karakter. }\end{array}$ & $\begin{array}{l}\text { Tingkat } \\
\text { Sekolah } \\
\text { Dasar }\end{array}$ & $\begin{array}{l}\text { Studi } \\
\text { Kepustak } \\
\text { aan } \\
\text { pendekat } \\
\text { an } \\
\text { kualitatif }\end{array}$ & 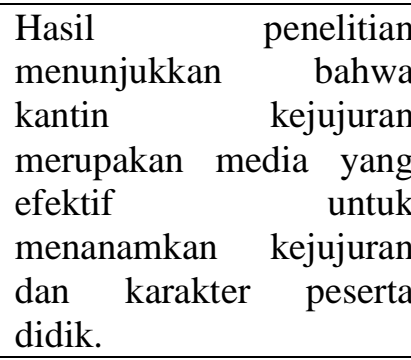 \\
\hline 8 & $\begin{array}{l}\text { Kusnan, } \\
\text { Ach., \& } \\
\text { Nur } \\
\text { Farida, } \\
\text { Eva. }\end{array}$ & 2020 & 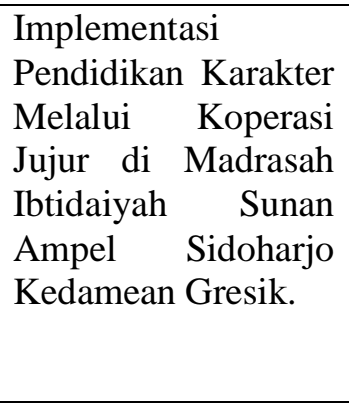 & $\begin{array}{l}\text { Madrasah } \\
\text { Ibtidaiyah } \\
\text { Sunan Ampel } \\
\text { Sidoharjo } \\
\text { Kedamean } \\
\text { Gresik }\end{array}$ & Kualitatif & $\begin{array}{l}\text { Hasil penelitian } \\
\text { menunjukkan bahwa } \\
\text { program koperasi jujur } \\
\text { atau bisa disebut dengan } \\
\text { kantin kejujuran } \\
\text { dilaksanakan dengan } \\
\text { system self service atau } \\
\text { melayani diri sendiri } \\
\text { tanpa ada penjaga. }\end{array}$ \\
\hline 9 & $\begin{array}{l}\text { Pramuji } \\
\text { yanti } \\
\text { Khotima } \\
\text { h, Rita., } \\
\text { Suryo } \\
\text { Putro, } \\
\text { Doni., } \\
\text { \& dkk }\end{array}$ & 2020 & $\begin{array}{l}\text { Penanaman Karakter } \\
\text { Kejujuran Melalui } \\
\text { Kantin Anti Korupsi } \\
\text { pada Siswa SD/MI } \\
\text { Ngargorejo, } \\
\text { Ngamplak, Boyolali. }\end{array}$ & $\begin{array}{l}\text { SD/MI } \\
\text { Ngargorejo, } \\
\text { Ngamplak, } \\
\text { Boyolali }\end{array}$ & Kualitatif & $\begin{array}{l}\text { Hasil penelitian } \\
\text { menunjukkan bahwa } \\
\text { penanaman karakter jujur } \\
\text { melalui kantin kejujuran } \\
\text { sudah bisa dikatakan } \\
\text { berhasil dan baik } \\
\text { meskipun rang } \\
\text { penataan ruang yang } \\
\text { sangat sederhana. }\end{array}$ \\
\hline 10 & $\begin{array}{l}\text { Dewi, } \\
\text { Tri } \\
\text { Ratna., } \\
\text { Rohmah } \\
\text { Miftahu } \\
\text { r., \& } \\
\text { Kurniaw } \\
\text { an, } \\
\text { Rely. }\end{array}$ & 2020 & $\begin{array}{lr}\text { Kantin } & \text { Kejujuran } \\
\text { Sebagai } & \text { Sarana } \\
\text { Penanaman } & \text { Sifat } \\
\text { Jujur pada } & \text { Peserta } \\
\text { Didik di } & \text { Sekolah } \\
\text { Tingkat Dasar }\end{array}$ & $\begin{array}{l}\text { Sekolah } \\
\text { Tingkat } \\
\text { Dasar }\end{array}$ & Kualitatif & $\begin{array}{l}\text { Hasil penelitian } \\
\text { menunjukkan } \\
\text { kantin } \\
\text { merupakan sarana yang } \\
\text { tepat diterapkan sebagai } \\
\text { upaya penanaman sifat } \\
\text { dan karakter jujur peserta } \\
\text { didik di tingkat sekolah } \\
\text { dasar. }\end{array}$ \\
\hline 11 & $\begin{array}{l}\text { Fatmaw } \\
\text { ati, Suci }\end{array}$ & 2020 & $\begin{array}{l}\text { Kontribusi Kantin } \\
\text { Kejujuran dalam } \\
\text { Mendukung } \\
\text { Pelaksanaan } \\
\text { Pendidikan Karakter } \\
\text { di SD Islam Plus } \\
\text { As-Sa'adatain } \\
\text { Cinere Depok }\end{array}$ & $\begin{array}{l}\text { SD Islam } \\
\text { Plus As- } \\
\text { Sa'adatain } \\
\text { Cinere } \\
\text { Depok }\end{array}$ & Kualitatif & $\begin{array}{l}\text { Hasil penelitian } \\
\text { menunjukkan bahwa } \\
\text { kantin kejujuran di SD } \\
\text { Islam Plus As-Sa'adah } \\
\text { sudah baik dan memenuhi } \\
\text { konsep kantin kejujuran } \\
\text { yang digagas oleh KPK. }\end{array}$ \\
\hline 12 & $\begin{array}{l}\text { Sifghotu } \\
\text { llah, } \\
\text { Ahmad } \\
\text { Arif }\end{array}$ & 2020 & $\begin{array}{l}\text { Implementasi Kantin } \\
\text { Kejujuran Terhadap } \\
\text { Penguatan Karakter } \\
\text { Siswa SDN Pegulon } \\
\text { 02 Kendal }\end{array}$ & $\begin{array}{l}\text { SDN Pegulon } \\
02 \text { Kendal }\end{array}$ & Kualitatif & $\begin{array}{l}\text { Hasil penelitian } \\
\text { menunjukkan bahwa } \\
\text { system yang dilaksanakan } \\
\text { adalah self system artinya } \\
\text { para siswa melayani } \\
\text { dirinya sendiri untuk } \\
\text { melakukan transaksi. }\end{array}$ \\
\hline
\end{tabular}


3571 Implementasi Pendidikan Karakter Integritas Sub Nilai Kejujuran melalui Program Kantin Kejujuran di Sekolah Dasar - Annisa' Auliyairrahmah, Sukron Djazilan, Nafiah, Sri Hartatik

DOI: https://doi.org/10.31004/edukatif.v3i6.939

Dari tabel telaah sistematis diatas di deskripsikan kembali analisis dari 12 sumber data pustaka yang diperoleh secara mendalam sebagai berikut :

Menurut hasil penelitian yang dilakukan oleh Yulianti pada tahun 2013 dengan judul Kajian Kantin Jujur dalam Rangka Peningkatkan Pendidikan Karakter di Tingkat Sekolah Dasar untuk Mewujudkan Siswa yang Kreatif (Studi Kasus di Sdn Panggungrejo 04 Kepanjen), hasil penelitian ini menunjukkan bahwa dalam menanamkan strategi siswa yang mandiri, maka peserta didik diikut sertakan dalam kegiatan kantin kejujuran sebagai wahana belajar dan melatih skill entrepreneurship, pribadi yang ulet, terampil, jujur dan kelak akan menjadi manusia yang bertanggung jawab. Keterlibatan peserta didik dalam program kantin kejujuran dimulai dari tahap persiapan yaitu dengan membantu mempersiapkan makanan dan minuman jajanan yang dijual di meja masing - masing kelas, pelaksanaan seperti menyiapkan kaleng uang recehan untuk kembalian dan kaleng uang untuk pembayaran dan pencatatan laporan atau hasil evaluasi. Selain itu pengelelolaan kantin kejujuran di Sdn Panggungrejo 04 dilakukan dengan system tersturktur.

Menurut hasil penelitian yang dilakukan oleh Atikah, Nyimas pada tahun 2016 dengan judul Pengaruh Pelaksanaan Kantin Kejujuran dalam membentuk Akhlak Siswa di Sdn 144 palembang, hasil penelitian ini menunjukkan adanya pengaruh yang tinggi yang diperoleh dari besarnya korelasi product moment sebesar 0,980692744 yang letaknya antara 0,800 sampai 1,00 . Yang mana menunjukkan adanya kesadaran para siswa dalam menanggapi keberadaan kantin kejujuran mereka setuju dengan adanya penerapan kantin kejujuran di sekolah dan dapat dipercaya dan dibuktikan bahwasannya kantin kejujuran merupakan media pendidikan yang relevan dalam membentuk serta menanamkan nilai-nilai kebaikan.

Menurut hasil penelitian yang dilakukan oleh Nawawi, Imam pada tahun 2017 dengan judul Pengembangan Budaya Jujur Berbasis Kantin Kejujuran bagi Murid Sekolah Dasar di SD Sawojajar I Kota Malang menunjukkan hasil bahwasannya pelaksanaan pengembangan budaya jujur berbasis kantin kejujuran tersebut belum dilakukan secara baik, sistematik, belum adanya pemograman secara khusus, dan belum optimal. Selain itu tata tertib yang ada disusun secara sepihak tanpa adanya musyawarah dan sosialisasi keseluruh kelas yang menjadikan kurangnya komitmen untuk mewujudkannya yang mengakibatkan penanaman nilai-nilai kejujuran belum sepenuhnya terakomodasi.

Menurut hasil penelitian yang dilakukan oleh Dewi Subekti, Fadzilah pada tahun 2018 dengan judul Implementasi Nilai Karakter Jujur Melalui Program Kantin Kejujuran di Sdn Banyubening I Gunungkidul. Hasil penelitian ini menunjukkan bahwa dalam mengimplementasikan nilai karakter jujur melalui program kantin kejujuran di SDN Banyubening I Gunungkidul ada tiga komponen penting yaitu kegiatan rutin, kegiatan spontan, dan keteladanan. Kegiatan rutin meliputi kegiatan membuka dan mengunjungi kantin kejujuran, kegiatan penyediaan makanan dan minuman, kegiatan jual beli, kegiatan pencatatan persediaan dan pembelian, dan kegiatan pelaporan di kantin kejujuran. Selanjutnya kegiatan spontan yang dilakukan ketika pendapatan kantin kejujran kurang dari pendapatan yang seharusnya, adanya selisih pendapatan dan ketika ada siswa yang lupa atau tidak membayar di kantin kejujuran, ketika ada selisih pendapatan maka pengelola kantin kejujuran akan melapor ke kepala sekolah dan akan ditindak lanjuti dengan memberikan pembinaan kepada siswa. Yang terakhir yakni keteladanan artinya bapak/ibu guru dan karyawan yang ada di SDN Banyubening I Gunungkidul juga sering membeli di kantin kejujuran dan melaksanakan transaksi seperti halnya dengan siswa, hal ini dilakukan dengan maksudkan untuk memberikan keteladanan kepada siswa sehingga nantinya dapat dicontoh oleh siswa.

Menurut penelitian yang dilakukan oleh Solikah, Maratus pada tahun 2018 dengan judul Pendidikan Karakter Kejujuran Melalui Kantin Kejujuran di SD Muhammadiyah Purwokerto menunjukkan hasil bahwasannya implementasi pendidikan karakter melalui kantin kejujuran dilakukan dengan self service system yang artinya siswa melayani dirinya sendiri makanan dan minuman apa yang dia inginkan kemudian 
3572 Implementasi Pendidikan Karakter Integritas Sub Nilai Kejujuran melalui Program Kantin Kejujuran di Sekolah Dasar - Annisa' Auliyairrahmah, Sukron Djazilan, Nafiah, Sri Hartatik

DOI: https://doi.org/10.31004/edukatif.v3i6.939

menaruh uang ke dalam tabung atau kaleng yang telah disediakan. Hal tersebut yang nantnya dapat melatih siswa untuk selalu berperilaku dan bersikap jujur dalam kehidupan sehari-harinya.

Menurut penelitian yang dilakukan oleh (Sari, 2019) dengan judul Kajian Kantin Jujur dalam Rangka Peningkatkan Pendidikan Karakter di Tingkat Sekolah Dasar untuk Mewujudkan Siswa yang Jujur (Studi Kasus di Sdn 2 Kranji) menunjukkan hasil bahwasannya strategi pelaksanaan pendidikan karakter siswa di Sdn 2 Kranji melalui kantin kejujuran dengan melibatkan siswanya dalam kegiatan kantin jujur yaitu mulai dari tahap persiapan, pelaksanaan, dan pencatatan laporan atau hasil evaluasi. Model pelaksanaan kantin jujur ini antara lain yaitu makanan dan minuman dari penyetor dikumpulkan dikantin, kemudian petugas kantin dibantu oleh jadwal piket yang berisikn perwakilan siswa kelas lima, lalu menyiapkan kaleng uang kembalian dan uang pembayaran. Dalam penelitian ini menunjukkan manajemen pelaksanaan kantin kejujuan di Sdn 2 Kranji dilakukan dengan system terstruktur.

Menurut penelitian yang dilakukan oleh Anam, Khoirul, \& Sakiyati, IIs Devi pada tahun 2019 dengan judul Kantin Kejujuran sebagai Upaya Pembentukan Karakter. Hasil penelitian ini menunjukkan bahwasanya kantin kejujuran merupakan media yang sangat efektif untuk menanamkan kejujuran pada peserta didik.

Menurut penelitian yang dilakukan oleh Kusnan, Ach., \& Nur Farida, Eva pada tahun 2020 dengan judul Implementasi Pendidikan Karakter Melalui Koperasi Jujur di Madrasah Ibtidaiyah Sunan Ampel Sidoharjo Kedamean Gresik menunjukkan hasil penelitian bahwasannya pendidikan karakter jujur dilakukan melelui pembiasaan-pembiasaan disekolah, salah satunya melalui koperasi jujur yang meliputi kegiatan membuka dan mengujungi koperasi jujur, kemudian menyediakan alat tulis, minuman dan makanan, serta kegiatan transaksi jual beli di koperasi jujur tersebut. Namun, kenyataan yang ditemui dilapangan implementasi koperasi jujur dalam melatih karakter jujur di Madrasah Ibtidaiyah Sunan Ampel ini belum sepenuhnya berhasil, hal ini dikarenakan masih adanya beberapa siswa yang mengambil barang tanpa membayarnya.

Selanjutnya yaitu penelitian yang dilakukan oleh Pramujiyanti Khotimah, Rita., Suryo Putro, Doni., \& dkk pada tahun 2020 dengan judul Penanaman Karakter Kejujuran Melalui Kantin Anti Korupsi pada Siswa SD/MI Ngargorejo, Ngamplak, Boyolali menunjukkan hasil penelitian bahwasannya pelaksanaan program menunjukkan bahwa nilai-nilai karakter kejujuransiswa yang diinternalisasikan melalui kantin anti korupsi di SD/MI Ngargorejo, Ngamplak, Boyolali telah tertanamkan dengan baik yang dibuktikan dengan siswa yang telah menunjukkan sikap jujur, disiplin, dan mandiri. Dengan menggunakan teknik pelayanan self-srvice system dapat dijadikan sebagai media yang baik dan tepat dalam penanaman karakter jujur para siswa. Akan tetapi kantin anti korupsi di setting dengan sangat sederhana dan belum sepenuhnya bisa dikatakan sebagai kantin pada umunya.

Menurut penelitian yang dilakukan oleh Dewi, Tri Ratna., Rohmah Miftahur., \& Kurniawan, Rely pada tahun 2020 dengan judul Kantin Kejujuran Sebagai Sarana Penanaman Sifat Jujur pada Peserta Didik di Sekolah Tingkat Dasar. Dalam penelitian ini menunjukkan hasil bahwasannya konsep pengelolaan kantin kejujuran dibagi menjadi 4 bagian yaitu perencanaan, pengorganisasian, pelaksanaan, dan pengevaluasian. Kemudian kantin kejujuran merupakan sebuah sarana yang tepat untuk membentuk, menanamkan nilai-nlai yang baik pada diri peserta didik di tingkat sekolah dasar.

Menurut penelitian yang dilakukan oleh Fatmawati, Suci pada tahun 2020 dengan judul Kontribusi Kantin Kejujuran dalam Mendukung Pelaksanaan Pendidikan Karakter di SD Islam Plus As-Sa'adatain Cinere Depok. Hasil penelitian ini menunjukkan bahwa kantin kejujuran di SD Islam Plus As-Sa'adatain sudah cukup baik dan mirip dengan konsep kantin kejujuran yang digagas oleh Komisi Pemberantas Korupsi (KPK). Namun sangat disayangkan dalam pelaksanaannya belum optimal karena ada beberapa hal yang belum berjalan secara konsisten, terlepas dari hambatan-hambatan tersebut kantin kejujuran sudah bisa berkonstribusi sebagai media pembiasaan karakter yang mendukung pelaksanaan pendidikan karakter di sekolah. 
3573 Implementasi Pendidikan Karakter Integritas Sub Nilai Kejujuran melalui Program Kantin Kejujuran di Sekolah Dasar - Annisa' Auliyairrahmah, Sukron Djazilan, Nafiah, Sri Hartatik

DOI: https://doi.org/10.31004/edukatif.v3i6.939

Menurut penelitian yang dilakukan oleh Sifghotullah, Ahmad Arif pada tahun 2020 dengan judul Implementasi Kantin Kejujuran terhadap Penguatan Karakter Siswa SDN Pegulon 02 Kendal. Hasil penelitian ini menunjukkan bahwa semua siswa di SDN Pegulon 02 Kendal telah mengetahui makna apa itu jujur, yang mana berawal dari rasa tahu tersebut akhirnya sekolah mengadakan kantin kejujuran untuk menerapkan dan melatih karakter jujur siswa. Sistem kantin kejujuran pada SDN 02 Pegulon Kendal ini sama halnya dengan system kantin kejujuran di berberapa sekolah, yaitu self-service system yang artinya siswa melayani dirinya sendiri untuk melakukan transaksi.

\section{Implementasi pendidikan karakter integritas sub nilai kejujuran melalui program kantin kejujuran disekolah dasar.}

Berdasarkan hasil analisis dokumen ditemukan adanya kesesuaian antara penelitian ini dengan riset terdahulu yang dijadikan sumber data. Sebagaimana yang telah kita ketahui bahwasannya perilaku tidak jujur seperti korupsi, suap, dan lain sebagainya masih sering kita temui, ketidakjujuran pada diri peserta didik bukan hanya sekedar mencontek waktu ulangan, tetapi juga sudah sampai ke dalam urusan tindak kriminalitas. Pendidikan kita sesungguhnya melewatkan atau mengabaikan beberapa dimensi penting dalam pendidikan, yaitu olah raga (kinestetik), olah rasa (seni), dan olah hati (etik dan spiritual) Effendy (2016). Apa yang selama ini kita lakukan baru sebatas olah pikir yang akan menumbuhkan kecerdasan akademis tanpa memikirkan peluang adanya kemerosotan karakter pada diri peserta didik. Persoalan diatas perlu diatasi dengan sinergi berkelanjutan antara pemerintah, sekolah, orang tua dan maysarakat melalui pendidikan karakter. Pendidikan karakter yang difokuskan dalam pembahasan ini yaitu pendidikan karakter nilai integritas. Effendy, Muhadjir (2018:9) dalam bukunya yang berujudul "Konsep dan Pedoman Penguatan Pendidikan Krakter", menuliskan bahwa pendidikan karakter integritas merupakan nilai yang mendasari perilaku yang didasarkan pada upaya menjadikan dirinya sebagai orang yang selalu dapat dipercaya dalam perkataan, tindakan, dan pekerjaan.

(Samani \& Hariyanto, 2013) menyatakan bahwa implementasi pendidikan karakter melalui transformasi budaya dan perikehidupan sekolah, dirasakan lebih efektif daripada mengubah kurikulum dengan menambahkan materi pendidikan karakter ke dalam muatan kurikulum. Oleh karena itu melaksanakan pendidikan karakter melelui program diluar kegiatan pembelajaran sangat penting untuk diterapkan. Salah satu program sekolah yang dapat menjadi sarana untuk mengimplementasikan pendidikan karakter integritas pada peserta didik ialah melalui program kantin kejujuran. Kantin kejujuran adalah tempat menjual berbagai makanan dan minuman uniknya kantin kejujuran ini tidak mempunyai penjaga atau penjual seperti yang kita lihat kantin pada umunya.

Kantin kejujuran ini juga merupakan salah satu kegiatan pembiasaan melalui budaya sekolah. Effendy, Muhadjir (2018:9) dalam bukunya yang berujudul "Konsep dan Pedoman Penguatan Pendidikan Krakter", menjelaskan bahwa kegiatan pembiasaan melalui budaya sekolah dapat dibentuk dalam proses kegiatan rutin, spontan, pengkondisian, dan keteladanan warga sekolah. Maka implementasi pendidikan karakter integritas melalui program kantin kejujuran terdapat 4 kegiatan dalam proses pelaksanaannya, yang menunjukkan bahwa pihak sekolah telah melakukan berbagai kegiatan agar pendidikan karakter integritas dapat diterapkan dengan baik kepada peserta didik melalui program kantin kejujuran. Adapun 4 kegiatan yang dilaksanakan sebagai berikut:

Kegiatan rutin . Wiyani (2013: 104) menyatakan bahwa kegiatan rutin yaitu kegiatan yang dilaksanakan peserta didik secara terus menerus dan konsisten setiap saat. Senada dengan pendapat diatas menurut Mulyasa (2012: 168) kegiatan rutin adalah pembiasaan yang dilakukan terjadwal dan dilakukan secara terus menerus. Pendapat tersebut diperkuat lagi oleh (Supraptriningrum \& Agustini, 2015) yang menyatakan bahwa kegiatan rutin ialah kegiatan yang dilakukan secara terus-menerus dan konsisten setiap saat. Menurut (Nurul Annisa et al., 2020) karakter seseorang akan terbentuk bila aktivitas dilakukan secara berulang-ulang secara rutin 
3574 Implementasi Pendidikan Karakter Integritas Sub Nilai Kejujuran melalui Program Kantin Kejujuran di Sekolah Dasar - Annisa' Auliyairrahmah, Sukron Djazilan, Nafiah, Sri Hartatik

DOI: https://doi.org/10.31004/edukatif.v3i6.939

sehingga menjadi suatu kebiasaan. Rutinitas ini dilaksanakan setiap hari di kantin kejujuran dengan tujuan mengiplementasikan pendidikan karakter integritas pada peserta didik. Kegiatan rutin yang dilaksanakan pada kantin kejujuran meliputi kegiatan membuka dan mengunjungi kantin kejujuran , kegiatan penyediaan makanan dan minuman, kegiatan jual beli, kegiatan pencatatan persediaan dan pembelian, dan kegiatan pelaporan di kantin kejujuran.

Kegiatan spontan, Kegiatan kedua yang dilakukan dalam mengimplementasikan pendidikan karakter integritas kepada peserta didik yaitu kegiatan spontan. Kegiatan ini dilakukan ketika pendapatan kantin kejujuran kurang dari pendapatan atau ketika ada selisih pendapatan, ketika ada selisih pendapatan maka pengelola kantin kejujuran akan melapor ke kepala sekolah dan akan ditindak lanjuti dengan memberikan pembinaan kepada siswa, juga ketika ada siswa yang lupa atau tidak membayar di kantin kejujuran Menurut Gunawan (2012) menjelaskan bahwa kegiatan spontan adalah kegiatan yang dilakukan siswa secara spontan pada saat itu juga, saat didapati ada siswa yang spontan lupa belum mebayar bahkan sengaja tidak membayar maka pada saat itu juga ia akan mendapat teguran yang menidik.

Keteladanan Kegiatan yang tak kalah pentingnya untuk dilakukan dalam mengiplementasikan pendidikan karakter kepada peserta didik melalui program kantin kejujuran yaitu keteladanan. Keteladanan merupakan timbulnya sikap dan perilaku siswa karena meniru sikap dan perilaku guru atau dengan kata lain siswa menjadikan guru sebagai role model guru seharusnya dapat menjadi teladan atau contoh yang baik dalam berbagai aspek seperti kejujuran, kedisiplinan, kerapian, kebersihan, tanggung jawab, dan lain sebagainya (Kusumawardani et al., 2021). Samani dan Hariyanto (2016: 146) menyatakan bahwa keteladanan dapat dilihat dari timbulnya sikap dan perilaku peserta didik karena meniru perilaku dan sikap guru dan tenaga kependidikan disekolah. Senada dengan pendapat diatas Sujiati (2018: 63) dalam bukunya yang berjudul "Menebar Penguatan Pendidikan Karakter Sampai ke Pelosok Negeri" menjelaskan bahwa sikap keteladanan guru kepada peserta didik banyak dilakukan melalui tindakan sehari-hari. Jika dilihat dalam konteks kegiatan keteladanan dalam mengiplementasikan pendidikan karakter melalui kantin kejujuran maka, keteladanan yang dimaksudkan disini ialah bahwasannya para pendidik maupun karyawan di sekolah juga dihimbau untuk sering melakukan transaksi jual beli di kantin kejujuran seperti yang dilakukan para siswa. Kegiatan ini diharapkan dapat menjadi keteladanan yang nantinya dapat dicontoh oleh para peserta didik.

Kegiatan pengondisian. Menurut Wiyani (2013: 105) menyatakan bahwa pengondisian merupakan penciptaan kondisi yang mendukung keterlaksanaan pendidikan karakter. Kegiatan pengondisian dalam implementasi pendidikan karakter integritas melalui program kantin kejujuran dilakukan dengan memasang banner kantin kejujuran, menempel slogan-slogan tentang kejujuran, meyiapkan tempat makanan dan minuman, daftar harga, menyediakan kotak uang, peringatan untuk membayar dan tata cara pembelian serta tata tertib.

Dari beberapa uraian peneliti diatas, bahwasannya dalam mengimplementasikan pendidikan karakter integritas melalui program kantin kejujuran terdapat 4 kegiatan dalam proses pelaksanaannya, yaitu kegiatan rutin, kegiatan spontan, kegiatan keteladanan, dan kegiatan pengondisian. Hal tersebut sesuai dengan hasil penelitian yang dilakukan oleh Dewi Subekti, Fadzilah (2018) di SDN Banyubening I Gunungkidul. Pertama, kegiatan rutin dalam implementasi nilai karakter jujur melalui program kantin kejujuran di SDN Banyubening I Gunungkidul meliputi kegiatan membuka dan mengunjungi kantin kejujuran, serta kegiatan jual beli di kantin kejujuran. Kedua, kegiatan spontan dalam implementasi nilai karakter jujur melalui program kantin kejujuran di SDN Banyubening I Gunungkidul dilakukan ketika terdapat selisih pendapatan dan ketika ada siswa yang lupa atau tidak membayar di kantin kejujuran. Ketiga, kegiatan keteladanan dalam implementasi nilai karakter jujur melalui program kantin kejujuran di SDN Banyubening I Gunungkidul yaitu bapak/ibu guru dan karyawan yang ada juga sering membeli di kantin kejujuran dan melaksanakan proses jual beli seperti siswa. Keempat, kegiatan pengondisian dalam implementasi nilai karakter jujur melalui program 
3575 Implementasi Pendidikan Karakter Integritas Sub Nilai Kejujuran melalui Program Kantin Kejujuran di Sekolah Dasar - Annisa' Auliyairrahmah, Sukron Djazilan, Nafiah, Sri Hartatik

DOI: https://doi.org/10.31004/edukatif.v3i6.939

kantin kejujuran di SDN Banyubening I Gunungkidul dilakukan dengan adanya banner kantin kejujuran, tempat makanan dan minuman, slogan tentang kejujuran dan lain sebagainya yang mendukung keterlaksanaan pendidikan karakter di SDN Banyubening I Gunungkidul. Selain bebebrapa kegiatan yang sudah dijelaskan diatas, usaha sekolah untuk menunjang keberhasilan dalam mengimplementasikan pendidikan karakter integritas melalui program kantin kejujuran ialah dengan menggunakan 2 sistem yang diharapkan dapat lebih menambah tingkat keberhasilan dalam mengimplementasikan pendidikan karakter, 2 sistem tersebut sebagai berikut:

Sistem self-service. Sistem yang dilakukan pihak sekolah untuk penerapkan pendidikan karakter integritas di sekolah dasar yaitu menggunakan self-service yang artinya para peserta didik melayani dirinya sendiri baik dalam pemilihan barang apa yang hendak dibeli sampai membayar sesuai harga yang ada pada barang yang sudah dipilih. Kurniawan (3013: 130-131) mengemukakan beberapa indicator dalam penyediaan kantin jujur yaitu transaksi jual-beli yang diterapkan adalah self-service, artinya pembeli melayani dirinya sendiri dalam proses pembelian barang yang dibutuhkan. Hal tersebut senada dengan hasil penelitian yang dilakukan oleh Kusnan, Ach., \& Nur Farida, Eva (2020) di Madrasah Ibtidaiyah Sunan Ampel Sidoharjo Kedamean Gresik, bahwasannya implementasi pendidikan karakter melalui kantin kejujuran di Madrasah Ibtidaiyah Sunan Ampel ini dilakukan dengan sistem self-service atau melayani diri sendiri tanpa ada yang berjaga, peserta didik mengambil barang sendiri, melihat harga kemudian membayarnya sendiri ditempat uang yang tersedia, jika ada kembalian peserta didik dapat mengambil sendiri uang kembaliannya di toples uang yang tersedia.

Sistem pelibatan siswa.Sistem yang kedua yang diterapkan pihak sekolah dalam mengimplementasikan pendidikan karakter integritas melalui program kantin kejujuran yaitu pelibatan siswa, sistem pelibatan siswa ini dikemas dalam bentuk tugas piket. Hal tersebut sesuai dengan hasil penelitian yang dilakukan oleh Yulianti (2013) di SDN Panggungrejo 04 Kepanjen yaitu anak-anak disekolah diikutkan dalam kegiatan kantin kejujuran sebagai wahana belajar siswa, dan pelibatan siswa ini dikemas dalam bentuk tugas piket.

\section{Kendala yang dihadapi dalam implementasi pendidikan karakter integritas melalui program kantin kejujuran di sekolah dasar}

Dalam mengimplementasikan pendidikan karakter integritas di sekolah dasar, tentu tak lepas dari kendala yang dihadapi dalam proses pelaksanaannya. Dari hasil penelitian diatas akan dijelaskan kembali secara rinci kendala-kendala yang dihadapi dalam implmentasi pendidikan karakter integritas di sekolah dasar sebagai berikut: Pertama, masih terdapat beberapa siswa yang kesulitan untuk jujur hal tersebut sesuai dengan hasil penelitian yang dilakukan oleh Yulianti (2013) di SDN Panggungrejo 04 Kepanjen yaitu masih terdapat siswa yang mengalami kesulitan untuk jujur khususnya pada siswa kelas 1 yang mana sebagian besar dari mereka belum mengerti uang. Kedua, ditemui beberapa siswa yang lupa atau bahkan membeli tanpa membayar hal ini senada dengan hasil penelitian yang dilakukan oleh Dewi Subekti, Fadzilah (2018) di SDN Banyubening I Gunungkidul yang menunjukkan bahwa ditemui beberapa siswa yang lupa atau tidak membayar saat membeli dikantin kejujuran. Ketiga, adanya selisih pendapatan yang disebabkan oleh sebagian peserta didik yang lupa bahkan tidak membayar pada saat membeli di kantin kejujuran. Keempat, belum optimal dalam pelaksanaannya, hal tersebut sesuai dengan hasil penelitian yang dilakukan oleh Solikah, Maratus (2018) di SD Muhammadiyah Purwokerto yang menunjukkan bahwa pelaksanaan implementasi pendidikan karakter di SD Muhammadiyah Purwokerto belum optimal. Kelima, membeli di luar jam operasional. Kurniawan (2013: 131) menyatakan bahwa tidak kalah pentingnya, penerapan kantin jujur di sekolah dilaksanakan atau beroperasi di jam-jam tertentu sehingga tidak menganggu kepentingan sekolah lainnya. Hal tersebut sesuai dengan hasil penelitian yang dilakukan oleh Kusnan, Ach., \& Nur Farida, Eva (2020) di Madrasah Ibtidaiyah Sunan Ampel Sukoharjo Kedamean Gresik yang menunjukkan masih adanya siswa yang tetap membeli barang di kantin jujur diluar jam operasional. 
3576 Implementasi Pendidikan Karakter Integritas Sub Nilai Kejujuran melalui Program Kantin Kejujuran di Sekolah Dasar - Annisa' Auliyairrahmah, Sukron Djazilan, Nafiah, Sri Hartatik

DOI: https://doi.org/10.31004/edukatif.v3i6.939

\section{Upaya yang dilakukan dalam mengatasi kendala yang dihadapi dalam implementasi pendidikan karakter integritas melalui program kantin kejujuran di sekolah dasar.}

Upaya yang dilakukan pihak sekolah untuk mengatasi kendala-kendala yang dihadapi pada saat proses penerapan pendidikan karakter di sekolah dasar. Pertama, dengan memberikan teguran dan selalu mengingatkan kepada seluruh peserta didik untuk segera membayar dan selalu membayar saat melakukan transaksi jual beli di kantin kejujuran Muslich (2011: 175) menyatakan bahwa guru perlu menegur peserta didik yang melakukan perilaku buruk dan mengingatkannya agar mengamalkan nilai-nilai yang baik sehingga guru dapat membantu mengubah tingkah laku mereka. Kedua, memberikan pembinaan secara tulus dan dilakukan secara terus menerus kepada seluruh peserta didik. Ketiga, peningkatan mutu pelayanan dan perbaikan menejemen pengelolaan pada kantin kejujuran agar implementasi pendidikan karakter integritas dapat terlaksana dengan baik. Hal tersebut sesuai dengan hasil penelitian yang dilakukan oleh (Anam \& Sakiyati, 2019) yang menyatakan bahwa salah satu upaya untuk mengatasi kendala tersebut yaitu dengan memperbaiki sistem pengelolaan yang ada pada kantin kejujuran. Hasil penelitian yang dilakukan Solikah, Maratus (2018) memperkuat hasil penelitian ini bahwa Dalam upaya untuk mengatasi kendala yang ada, peningkatan mutu pelayanan pada kantin kejujuran di SD Muhammadiyah Purwokerto adalah jalan yang terbaik.

\section{KESIMPULAN}

Berdasarkan hasil penelitian dan pembahasan, dapat di ambil simpulan bahwa implementasi pendidikan karakter integritas melalui program kantin kejujuran di sekolah dasar dapat dilaksanakan dengan 4 kegiatan dalam proses pelaksanaannya yaitu kegiatan rutin, kegiatan spontan, keteladanan, dan pengondisian. Serta terdapat 2 sistem yang dilakukan untuk menunjang keberhasilan implementasi pendidikan karakter integritas melalui program kantin kejujuran di sekolah dasar yaitu sistem self service dan sistem pelibatan peserta didik.

Kendala yang dihadapi dalam implementas pendidikan karakter integritas di sekolah dasar yaitu: 1) masih terdapat beberapa siswa yang kesulitan untuk jujur. 2) ditemui beberapa siswa yang lupa atau bahkan membeli tanpa membayar. 3) selisih pendapatan yang disebabkan oleh sebagian peserta didik yang lupa bahkan tidak membayar pada saat membeli di kantin kejujuran. 4) belum optimal dalam pelaksanaannya. 5) membeli diluar jam operasional. Upaya yang dilakukan dalam mengatasi kendala yang dihadapi dalam mengimplementasikan pendidikan karakter integritas di sekolah dasar antara lain: dengan memberikan teguran dan selalu mengingatkan kepada seluruh peserta didik untuk segera membayar dan selalu membayar saat melakukan transaksi jual beli di kantin kejujuran, memberikan pembinaan secara tulus dan dilakukan secara terus menerus kepada seluruh peserta didik, peningkatan mutu pelayanan dan perbaikan menejemen pengelolaan pada kantin kejujuran agar implementasi pendidikan karakter integritas dapat terlaksana dengan baik.

\section{DAFTAR PUSTAKA}

Agra, H. (2021). Implementasi Program Bina Pribadi Islam (BPI) Dalam Membentuk Karakter Peserta Didik. Edukatif: Jurnal Ilmu Pendidikan, Vol 2 No 5. Https://Doi.Org/10.31004/Edukatif.V3i5.802

Anam, K., \& Sakiyati, I. D. (2019). Kantin Kejujuran Sebagai Upaya Dalam Pembentukan Karakter. Al Qalam: Jurnal Ilmiah Keagamaan Dan Kemasyarakatan. Https://Doi.Org/10.35931/Aq.V0i0.130

Cindra Hendriana, E., \& Jacobus, A. (2016). Implementasi Pendidikan Karakter Di Sekolah Melalui Keteladanan Dan Pembiasaan. Http://Dx.Doi.Org/10.26737/Jpdi.V1i2.262

Effendy, M. (2016). Konsep Dan Pedoman Penguatan Pendidikan Karakter. 
3577 Implementasi Pendidikan Karakter Integritas Sub Nilai Kejujuran melalui Program Kantin Kejujuran di Sekolah Dasar - Annisa' Auliyairrahmah, Sukron Djazilan, Nafiah, Sri Hartatik

DOI: https://doi.org/10.31004/edukatif.v3i6.939

Esmael, A., \& Nafiah. (2018). Implementasi Pendidikan Karakter Religius Di Sekolah Dasar Khadijah Surabaya.

Hidayatullah, F. (2010). Pendidikan Karakter: Membangun Peradaban Bangsa. Surakarta: UNS Press\&Yuma Pusataka.

Juanda. (2010). Peranan Pendidikan Formal Dalam Proses Pembudayaan. Lentera Pendidikan : Jurnal Ilmu Tarbiyah Dan Keguruan, 1-5.

Kesuma, D., Triatna, C., \& Permana, J. (N.D.). Pendidikan Karakter: Kajian Teori Dan Praktik Di Sekolah. Bandung: Remaja Rosdakarya.

Khotimah, P. (2020). Penanaman Karakter Kejujuran Melalui Kantin Anti Korupsi Pada Siswa SD/MI Ngargoreko, Ngemplak, Boyolali. Https://Doi.Org/10.23917/Bkkndik.V2i1.11167

Kusumawardani, F., Akhwani, Nafiah, \& Taufiq, M. (2021). Pendidikan Karakter Berbasis Nilai-Nilai Pancasila Melalui Keteladanan Dan Pembiasaan Di Sekolah Dasar. Https://Doi.Org/DOI: Http://Dx.Doi.Org/10.24269/Jpk.V6.N1.2021.Pp1-10

Mustaghfiroh, I. (2017). Penanaman Akhlak Jujur Pada Siswa Melalui Penerapan Antin Kejujuran Di Smp Negri 1 Imogiri Bantul. 2017, 83.

Narwanti, S. (2011). Pendidikan Karakter. Yogyakarta: Familia.

Nawawi, I. (2017). Pengembangan Budaya Jujur Berbasis Kantin Kejujuran Bagi Murid Sekolah Dasar Di SD Sawojajar I Kota Malang. Jurnal Peagogika.

Nurul Annisa, M., Wiliah, A., \& Rahmawati, N. (2020). Pentingnya Pendidikan Karakter Pada Anak Sekolah Dasar Di Zaman Serba Digital. 2.

Rahayu, D. W. (2016). Internalisasi Nilai Karakter Melalui Budaya Sekolah.

Samani, M., \& Hariyanto. (2013). Konsep Dan Model Pendidikan Karakter. Bandung: Remaja Rosdakarya.

Sari, G. P. (2019). Kajian Kantin Jujur Dalam Rangka Peningkatan Pendidikan Karakter Di Tingkat Sekolah Dasar Untuk Mewujudkan Siswa Yang Jujur (Studi Kasus Di Sdn 2 Kranji). Https://Doi.Org/10.32585/Jdb.V2i1.182

Sitorus, L., \& Lasso, A. H. (2021). Pendidikan Karakter Peduli Lingkungan Melalui Pembiasaan Dan Pembudayaan Di Sekolah Menengah Pertama. Edukatif: Jurnal Ilmu Pendidikan, Vol 3 No 5. Https://Doi.Org/10.31004/Edukatif.3i5.755

Subekti, F. (2018). Implementasi Nilai Arakter Jujur Melaui Program Kantin Kejujuran Di Sdn Banyubening I Gunungkidul. 2018.

Supraptriningrum, \& Agustini. (2015). Membangun Karakter Siswa Melalui Budaya Sekolah Di Sekolah Dasar. Https://Doi.Org/10.21831/Jpk.V0i2.8625 